the vacancy caused by election to the presidency of Prof. J. B. Speakman (see Nature, 194, 435; 1962). Dr. A. R. Urquhart (the Cotton, Silk and Man-Made Fibres Research Association) has been re-elected as chairman of Council for the fortheoming year. Vice-chairman lented is Mr. A. W. Bayes (Ashton Bros, and (Go., Ltd.), in place of Mr. J. A. Nasmith (Leesona Holt, Ltd.), who has bcen elected honorary treasurer in place of Mr. A. F. W. Coulson. Mr. J. C. H. Hurd (heud of the Department of Textiles, Leicester College of Technolugy) has been reelected honorary secretary. Lord Barnby, immediate past-prosident of the Textile Institute, has been elected to be an honorary life member.

\section{Index Medicus and the U.S. National Library of Medicine}

THe note on Index Medicus, appearing in the March 31 issue of Nature, p. 1236, unfortunately fails lo give credit to the National I ibrary of Medicine, U.S. Department of Health, Education and Welfare, Public Health Service, Washington, D.C., which publishes Index Medicus eash month. Not only does the National Library of Medicine publish the Index: Medicus but also it renders valuable scrvice to references in medical literature.

\section{The Night Sky in July}

New moon occurs on July 1d. 23h. 53m. U.T., full moon on July $17 \mathrm{~d} .11 \mathrm{~h} .41 \mathrm{~m}$. and new moon on July $3 \mathrm{Id} .12 \mathrm{~h}$. $24 \mathrm{~m}$. The following conjunctions with the Moon tako place: July 5d. 07h., Venus $0.6^{\circ}$ N.; July 18d. 13h., Saturn $0.7^{\circ}$ S.; July 20 d. 18h., Jupiter $2^{\circ}$ N.; July 27d. 00h., Aldebaran $0.9^{\circ} \mathrm{S}$; J July $27 \mathrm{~d}$. $04 \mathrm{~h}$., Mars $4^{\circ} \mathrm{N}$. In addition to these conjunctions with the Moon, Venus is in conjunction with Regulus on July 12d. 00h., Venus being $1 \cdot 1^{\circ} \mathrm{N}$., and Mars with Aldebaran on July 23d. 13h., Mars being $5^{\circ} \mathrm{N}$. Thore is a penumbral eclipse of the Moon on July 17 and an annular eclipse of the Sun on July 31 , both invisible at Greenwich. Mercury is a morning star, but is not favourably placed for oluservation. Venus is an evening star, visible in the west after sunset. It sets at $22 \mathrm{~h} .20 \mathrm{~m} ., 21 \mathrm{~h} .55 \mathrm{~m}$. and $21 \mathrm{~h} .15 \mathrm{~m}$. on July 1,15 and 31 , respectively; its stellar magnitude is $\mathbf{- 3 \cdot 6}$. Its distance decreases during the month from 109 to 88 million miles and the visible portion of tho apparent disk decreases from 0.757 to 0.642 . Mars rises at $1 \mathrm{~h} .30 \mathrm{~m}$., $0 \mathrm{~h} .40 \mathrm{~m}$. and $0 \mathrm{~h} .10 \mathrm{~m}$. at tho beginning, middle and ond of the month, respectively. It is at a distance of 177 million miles from the Earth on July 15, and its stellar magnitudo is $+1 \cdot 4$. Jupiter rises at $23 \mathrm{~h}$. $00 \mathrm{~m}$., $22 \mathrm{~h}$. $00 \mathrm{~m}$. and $21 \mathrm{~h} .00 \mathrm{~m}$, on July 1,15 and 31 , respectively. It is in Aquarius, its stellar magnitude is -2.3 and its distance from the Earth in the middle of the month is 400 million miles. Saturn is in Capricornus, rising at $21 \mathrm{~h} .50 \mathrm{~m} ., 20 \mathrm{~h} .55 \mathrm{~m}$. and $19 \mathrm{~h} .50 \mathrm{~m}$. at the beginning, middle and end of the month, respectively. Its stellar magnitude is +0.4 and its distance from the Earth on July 15 is 835 million miles. Occultations of stars brighter than magnitude 6 are as follows, observations being made at Greenwich: July 15d. $21 \mathrm{~h}$. $35.5 \mathrm{~m}$., $\mu$ Sgr. $(D)$; July $21 \mathrm{~d}$. $00 \mathrm{~h}$. 30.4m., $\psi^{1}$ Aqr. $(D)$; July 2ld. 01h. 35.2m., $\psi^{1}$ Aqr. $(R)$; July $21 \mathrm{~d}$. $02 \mathrm{~h} .22 \cdot 0 \mathrm{~m}$., $\psi^{2}$ Aqr. $(R), \quad D$ and $R$ refer to disappearance and reappearance, respectively. The Delta Aquarid meteors are active at the and of the month, the maximum being on July 29 ; the radiant is at R.A. $22 \mathrm{~h}$. $36 \mathrm{~m}$., Dec. $-17^{\circ}$, and conditions aro favourable. The Earth is at aphelion on July 4 , its distance from the Sun being $94 \cdot 6$ million miles.

\section{Royal Society Appointments}

Mr. R. W. J. Keay has been appointed deputy executive secretary to the Royal Society of London. Mr. Keay is at present director of the Federal Depart. ment of l'orest Research in Nigeria.

Dr. J. N. Murrell, Department of Chomistry, University of shefficld, has been awarded a Mr. and Mrs. Johin Jaffé Donation Research Fellowship to enable him to continue his work on theorotical chemistry at the University of Sheffield.

\section{Announcements}

Mr. P. H. Fvans, of Consolidated Beryllium, Itt., has been appointed the fifth Robert Horne Memorial Lecturer of the Society of Chemical Industry. His lecture, entitled "Production Problems associated with the Element Beryllium", will be delivered in Swansea on January $18,1963$.

Trme following officors of the Nutrition Society have been elected: President, Dr. D. P. Cuthbertson; Hon. Secretary, Miss D. F. Hollingsworth; Hon. Treasurer, Dr. A. E. Bender; Ordinary Members of Council, Mr, A. E. Boyne, Dr. G. N. Jenkins, Miss J. W. Marr, Mr. D. S. Miller and Dr. J. A. B. Smith.

A meetinc of the Biochemical Society will be held in the Department of Biochemistry, University of Cambridge, during July 12-13. The programme will include a colloquium on "Control of Protein Biosynthesis-the Role of Nucleic Acid". Further information can be obtained from Dr. H. R. V. Arnstein, National Institute for Medical Research, The Ridgeway, Mill Hill, London, N.W.7.

A confentince on "Preparation of Case Studies for Education and Training in Administration and Management", arranged by the Welsh College of Advanced Technology in collaboration with the Cornparative Administration Trust, will be held at the College during July 5-7. Further information can bo obtained from Z. M. T. Tarkowski, Comparative Administration Trust, 30 St. George's Street, London, S.W.1.

THE fourteonth conference of the British Occupational Hygiene Society on "Control of Airborne Particles and Fumes" will be held in King's College, Newcastle upon Tyne, during September 19-20. Topies under discussion will include: the work of an occupational health service in environmental control; some observations on asbestosis; control of the vanadium hazard in two industries; an experimental Diesel-exhanst filter; some problems in the large-scale handling of beryllium; dust and fume control-the implementation of current legislation. Further information can be obtained from Dr. J. Steel, Department of Industrial Health, Medical School, King's College, Newcastle upon Tyne.

Enuatum. Due to an oversight in proof, Dr. J. B. Birks and L. G. Christophorou state that the following changes should be made to their article "Excimer Fluorescence of Aromatic Hydrocarbons in Solution" which appeared on p. 442 of the May 5 issue of Nature: Table 1. 3:4-Benzpyrene, $D_{1}=514 \mathrm{~m} \mu$, $v^{\prime}\left(M_{1}-D_{1}\right)=5,350 \mathrm{~cm} .^{-1}$ (values for specimen of highor purity); Table 2. Anthranthrene, $D_{1}=594 \mathrm{~m} \mu$. 